\title{
Analisis Total Electron Content (TEC) Menggunakan Continous Wavelet Transform Sebagai Indikator Prekursor Gempa Bumi Di Wilayah Provinsi Bengkulu
}

\author{
Laksamana Agung Aprillo ${ }^{1}$, Hendy Santosa ${ }^{2}$, Faisal Hadi ${ }^{3}$ \\ ${ }^{1}$ Program Studi Teknik Elektro, Fakultas Teknik Universitas Bengkulu \\ E-mail: Laksamanaagung08@gmail.com
}

\begin{abstract}
ABSTRAK
Bengkulu merupakan salah satu dari 34 provinsi di Indonesia yang menjadi kawasan megathrust. Sehingga provinsi Bengkulu sering dilanda banyak gempa besar dengan kedalaman dangkal. Dilakukan analisa anomali TEC berdasarkan tiga gelombang elektromagnetik yang diradiasikan gempa bumi. Anomali total electron content (TEC) dilihat melalui data sinyal radio frekuensi-ganda global positioning system (GPS).. Metode continous wavelet transform (CWT) digunakan untuk membagi analisa sinyal ke dalam beberapa bagian sesuai dengan range frekuensi gelombang elektromagnetik yaitu acoustic $(2.5 \mathrm{mHz}-3$ $\mathrm{mHz})$, gelombang gravity $(1 \mathrm{mHz}-2.8 \mathrm{mHz})$ dan gelombang rayleigh $(5 \mathrm{mHz}-33 \mathrm{mHz})$. Data pengamatan GPS selama 9 hari dihitung menggunakan metode Standar deviasi (2o) untuk melihat trend perubahan data. Dari analisa yang dilakukan terlihat anomali pada gempa bumi 12 September 2007 (7,9 Mw), gempa bumi 5 Maret 2010 (6,3 Mw) dan gempa bumi 4 Agustus $2011(6,0 \mathrm{Mw})$. Anomali terdeteksi 1 sampai 5 jam sebelum terjadi gempa bumi. Anomali TEC yang terjadi boleh jadi terkait dengan proses preseismik sebelum gempa bumi dan kemungkinan merupakan tanda-tanda awal terjadinya gempa bumi (prekursor).
\end{abstract}

Kata Kunci: gempa, total electron content, continous wavelet transform, standar deviasi

\section{ABSTRACT}

Bengkulu is one of 34 provinces in Indonesia which is a megathrust region. So Bengkulu province is often hit by many large earthquakes with shallow depth. TEC anomaly was analyzed based on three electromagnetic waves radiated by an earthquake. The total electron content (TEC) anomaly is seen through the global positioning system (GPS) dualfrequency radio signal data. The continuous wavelet transform (CWT) method is used to divide the signal analysis into several sections according to the electromagnetic wave frequency range of acoustic $(2.5 \mathrm{mHz})-3 \mathrm{mHz})$, gravity waves $(1 \mathrm{mHz}-2.8 \mathrm{mHz})$ and rayleigh waves $(5 \mathrm{mHz}-33 \mathrm{mHz})$. GPS observation data for 9 days is calculated using the Standard deviation (2o) method to see trends in data changes. The analysis shows anomalies in the September 122007 earthquake (7.9 Mw), the March 52010 earthquake $(6.3 \mathrm{Mw})$ and the August 42011 earthquake (6.0 Mw). Anomalies are detected 1 to 5 hours before an earthquake occurs. TEC anomalies that occur may be related to the process of preseismic before the earthquake and may be an early sign of an earthquake.

Keyword: $\begin{aligned} & \text { earthquake, total electron content, } \\ & \text { continous wavelet transform, standard } \\ & \text { deviation }\end{aligned}$

\section{Pendahuluan}

Indonesia terletak di daerah pertemuan 3 lempeng tektonik, yaitu lempeng Indo-Australia, Euroasia dan lempeng Pacific[1]. Gempa bumi adalah getaran asli dari dalam bumi, bersumber di dalam bumi yang kemudian merambat ke permukaan bumi akibat rekahan bumi pecah dan bergeser dengan keras[2]. Gempa bumi dan letusan gunung api memancarkan tiga gelombang, yaitu : Acoustic, Gravity, dan Reyleigh wave. [3].

Total Electron Content (TEC) merupakan sejumlah elektron yang terintegrasi pada pada slab khayal yang dibentuk berdasarkan jarak satelit ke receiver GPS di permukaan bumi[4]. Ionosfer menyebabkan sinyal GPS mengalami penundaan sebanding dengan TEC, di sepanjang jalan dari satelit GPS ke penerima. Waktu tunda dapat diketahui dari kombinasi geometri bebas linear (L4) dari pseudorange GPS dengan frekuensi ganda atau dari pengukuran fase pembawa. TEC yang berkolerasi dengan waktu tunda memungkinkan untuk dihitung menggunakan persamaan matematika [5]. Data TEC GPS menyimpulkan terdapat anomali, peningkatan atau penurunan nilai TEC sebelum dan selama gempa terjadi[6]. 
Penelitian tentang Anomaly Total Electron Content (TEC) sebelum gempa bumi kuat di Indonesia Tahun 2014 menunjukkan variasi anomali TEC muncul sebelum gempa bumi[7]. Pada tahun 2017 dilakukan penelitian yang berjudul Pre-Seismic Anomali Ionosphere Before The 2016 Kumamoto Erthquake. Penelitian ini mempelajari anomali gempa kumamoto pada tanggal 15 april 2016 dengan magnitude Mw 7.3 yang terjadi di jepang. Metode yang digunakan dapat mendeteksi anomali pada ionosfer beberapa puluh menit sebelum gempa terjadi[8]. Identifikasi Prekursor Beberapa Gempa Di Sumatera Melalui Analisis Total Electron Content (TEC) di Ionosfer Menggunakan Teknik Korelasi menunjukkan adanya anomali pada gempa dengan magnitude $6 \mathrm{Mw}$ hingga $9 \mathrm{Mw}$ [9]. Deteksi anomali TEC sebelum dan setelah gempa bumi hanya efektif apabila sebelum atau setelah gempa bumi tidak terjadi badai geomagnetik moderat atau kuat[10].

Hingga saat ini prekursor TEC yang jelas teridentifikasi sebelum gempa bumi masih menjadi perdebatan mengingat faktor-faktor lain seperti halnya aktivitas geomagnetik yang dapat juga memicu anomali yang sama[11]

Penelitian ini membahas anomali total electron content (TEC) yang teramati sebelum kejadian gempa bumi di provinsi Bengkulu. Pengamatan dilakukan dengan menggunakan data satelit GPS yang berada dalam jaringan Sumatran GPS Array (SuGAr) dengan magnitudo $>6 \mathrm{Mw}$. Analisa dilkukan berdasarkan range frekuensi gelombang elektromagnetik yang diradiasikan oleh gempa bumi.

Hasil penelitian dapat dipergunakan sebagai masukan dalam mengembangkan dan membangun sistem pengamatan TEC untuk keperluan studi prekursor gempa bumi sehingga bermanfaat dalam upaya mitigasi bencana gempa bumi.

\section{DATA DAn Metode Penelitian}

\section{A. Data Penelitian}

Data yang digunakan untuk melakukan perhitungan Total Electron Content (TEC) dalam penelitian ini menggunakan data beberapa stasiun penerima GPS yang berada jaringan Sumatran GPS Array (selanjutnya SuGAr). SuGAr merupakan jaringan stasiun pemantau GPS kontinyu yang dioperasikan oleh LIPI dan Earth Observatory of Singapore (EOS) Nanyang Technological University. SuGAr ini dimulai dengan memasang 6 buah stasiun cGPS (Continued GPS) pada tahun 2002. Dari waktu ke waktu, SuGAr
Tabel 1 Data Repository Gempa Bengkulu

\begin{tabular}{ccccccc} 
NO & YY & MM & DD & Lat & Lon & Mag \\
\hline $\mathbf{1}$ & 2007 & 09 & 12 & $-4,59$ & 101,22 & 7,9 \\
$\mathbf{2}$ & 2010 & 03 & 05 & $-3,85$ & 100,91 & 6,3 \\
$\mathbf{3}$ & 2011 & 08 & 04 & $-2,88$ & 100,97 & 6,0
\end{tabular}
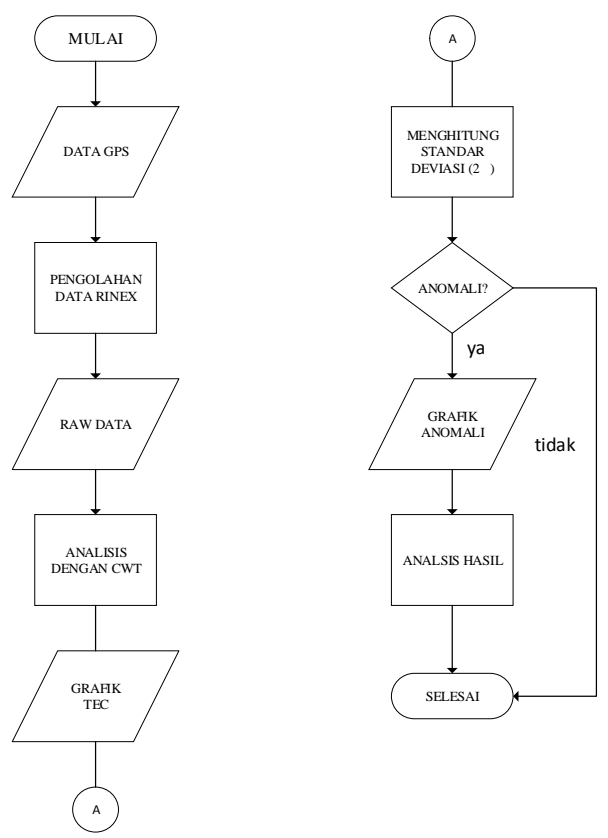

Gambar 1. Diagram Alir Penelitian

mengalami penambahan jumlah stasiun dan peningkatan dalam segi teknologi peralatan GPS, termasuk sistem telemetri data dari jaringan ini. Hingga tahun 2008, SuGAr telah memiliki stasiun sebanyak 33 buah tersebar dari wilayah Bengkulu Utara dan Aceh[9]. Data yang akan diolah harus dalam format RINEX (Receiver Independent Exchange). Data GPS SuGAr disimpan pada situs http://sopacold.ucsd.edu/dataBrowser.shtml dalam format hatanaka (.d) yang terkompres (zip).

Bengkulu merupakan salah satu dari 34 provinsi di Indonesia yang menjadi kawasan megathrust. Bengkulu merupakan suatu daerah dengan tatanan tektonik atau lempeng luas yang memiliki mekanisme pergerakan rata-rata, sesar naik. Sehingga provinsi Bengkulu sering dilanda banyak gempa besar dengan kedalaman dangkal. Dari catatan sejarah gempa, daerah ini di dominasi gempa dengan mekanisme sesar naik. Merujuk peta sumber dan bahaya gempa Indonesia tahun 2017, khusus Bengkulu setidaknya terdapat dua segmen subduksi, yakni megathrust Mentawai-Pagai dan megathrust Enggano. Adapun data gempa yang menjadi bahan penelitian dapat dilihat pada Tabel 1 


\section{B. Metode Penelitian}

Alur penelitian dapat dilihat pada Gambar 1. Mula-mula data RINEX yang diunduh dari SOPAC dikonversi ke format (.Cmn) menggunakan aplikasi GPS TEC, data yang didapat sudah dalam baris dan kolom. Data kembali diubah kedalam format (.Csv) agar dapat dibaca oleh MATLAB dan diubah kedalam bentuk matriks. Ukuran matriks bergantung pada lama waktu pengamatan satelit. Semakin lama berlangsungnya pengamatan, semakin besar juga matriks yang akan dihasilkan. Semakin besar matriks akan menggunakan kapasitas Random Access Memory (RAM) yang lebih besar pula, sehingga memengaruhi kecepatan pembacaan dan pemrosesan data. Data matriks dibagi setiap PRN yang berjumlah 32 untuk mempermudah analisa data. Analisa dilakukan dengan melihat data pengamatan PRN sebelum terjadinya gempabumi. Data kemudian diubah kedalam bentuk signal untuk kemudian di-filter menggunakan Continous Wavelet Transform. Untuk melihat anomali sebagai prekursor gempabumi perlu dilakukan perhitungan standar deviasi untuk melihat trend perubahan TEC. Standar deviasi digunakan untuk mengetahui sebaran data dan seberapa dekat titik per data dengan rata-rata data. Jika standar deviasi bernilai 0 berarti datanya sama persis tidak ada variasi, jika standar deviasi nya besar (>0) berarti sebaran data dari nilai rata-ratanya semakin bervariasi. Dalam hal ini digunakan dua kali standar deviasi (Mean-2 $\sigma$, dan Mean $+2 \sigma$ ). Sinyal yang jatuh pada jarak (Mean-2o, dan Mean+2б) maka dapat dikatakan anomali sebagai prekursor gempa bumi.

Di dalam penelitian ini, perhitungan dilakukan dengan menggunakan software GPS TEC Analysis versi 2.9.5, yaitu perangkat lunak yang dikembangkan oleh Dr. Gopi Seemala dari Indian Institute Of Geomagnetism (IIG) Navi Mumbai India. GPS TEC versi 2.9.5 ini adalah hasil pengembangan dari versi sebelumnya dengan berbagai peningkatan. Jadi software ini dapat melakukan komputasi nilai TEC dan mengubahnya ke dalam bentuk kolom dan baris. Perhitungan dilakukan selama 9 hari pengamatan.

Salah satu metode yang digunakan untuk analisis

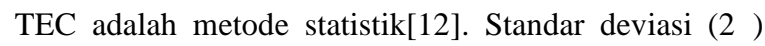
digunakan untuk melihat trend perubahan nilai TEC selama 9 hari. Nilai rata-rata dihitung pada data saat kejadian gempa, kemudian standar deviasi dihitung selama 9 hari sebelum gempa terjadi. Nilai $-2 \sigma$ dan $+2 \sigma$ dari nilai mean memiliki akurasi sebesar $95 \%$. sehingga digunakan sebagai indikator prekursor gempa bumi seperti pada Gambar 2

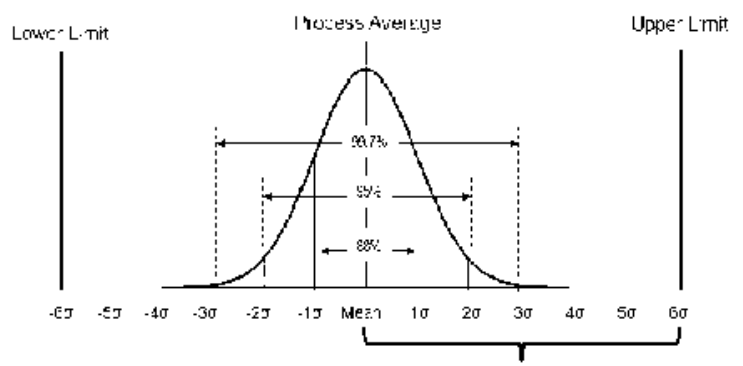

Gambar 2. Kurva Lonceng Standar Deviasi

Metode Transformasi berbasis Wavelet merupakan salah satu sarana yang dapat digunakan untuk menganalisis (meneliti) sinyal-sinyal nonstasioner. Dalam beberapa tahun terakhir ini, metode ini telah dibuktikan kegunaannya dan sangat populer di berbagai bidang ilmu. Analisis Wavelet dapat digunakan untuk menunjukkan kelakukan sementara (temporal) pada suatu sinyal, misalya dalam bidang geofisika (sinyal seismik), fluida, medik dan lain sebagainya. Metode Transformasi Wavelet ini dapat digunakan untuk menapis data atau meningkatkan mutu kualitas data; dapat juga digunakan untuk mendeteksi kejadiankejadian tertentu serta dapat digunakan untuk pemampatan data[13].

Selain itu Transformasi Wavelet juga dapat digunakan untuk analisis sinyal-sinyal non-stasioner (yaitu sinyal yang kandungan frekuensinya bervariasi terhadap waktu), karena berkaitan dengan kemampuannya untuk memisah-misahkan berbagai macam karakteristik pada berbagai skala[14].

Metode Continuous Wavelet Transform (CWT) dapat mengidentifikasi posisi dan kedalaman anomali tanggul lumpur Sidoarjo dengan menggunakan data SelfPotential[15]. CWT juga dapat melihat frekuensi dominan pada suara jantung manusia[16]

Pada penelitian ini, metode CWT digunakan untuk menganalisa data berdasarkan range frekuensi gelombang elektromagnetik yaitu Gravity (1 mHz-2,8 $\mathrm{mHz})$, Acoustic $(2,5 \mathrm{mHz}-3 \mathrm{mHz})$, dan gelombang Rayleigh $(5 \mathrm{mHz}-33 \mathrm{mHz})$.

\section{A. Gempa bumi 7.9 Mw}

\section{HASIL DAN PEMBAHASAN}

Gempa bumi ini terjadi pada tanggal 12 september 2007 pukul 11:10:23 (UTC) pada latitude 4,59 dan longitude 101,22 dengan hiposenter $10 \mathrm{Km}$. Setelah dilakukan pencarian nearby site pada SOPAC maka diperoleh dua stasiun GPS dalam jaringan SuGAr yaitu BSAT dan MLKN. 


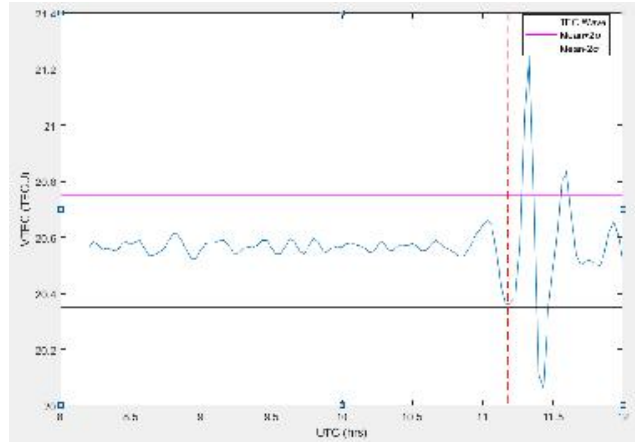

(a)

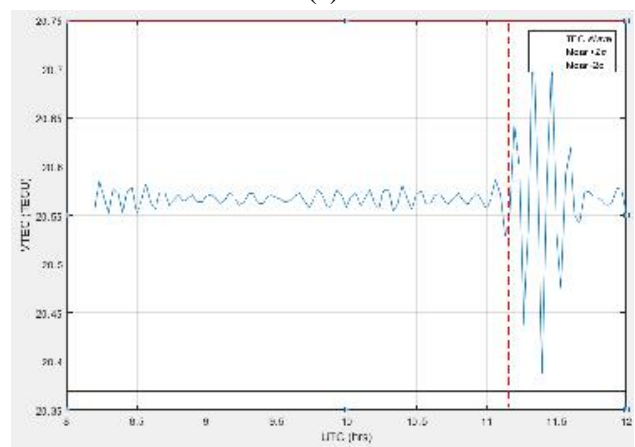

(b)

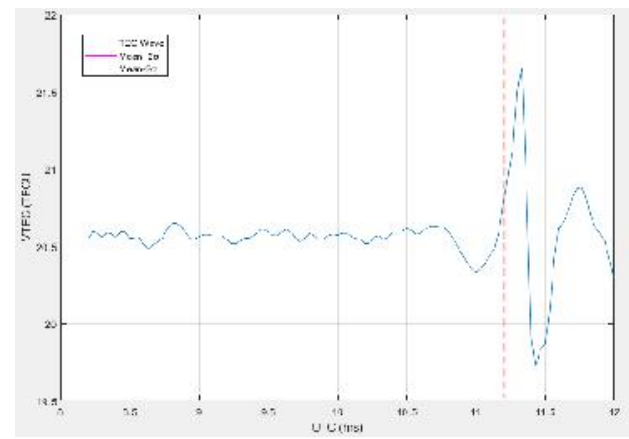

(c)

Gambar 3. (a) Gravity; Acoustic; (c) Rayleig

Tabel 2. Hasil Perhitungan Mean dan Standar Deviasi

\begin{tabular}{|c|c|c|c|c|c|c|}
\hline Satelit & DOY & Mean & $\Sigma$ & $2 \sigma$ & $\begin{array}{c}\text { Mean- } \\
2 \sigma\end{array}$ & Mean $+2 \sigma$ \\
\hline \multirow{9}{*}{$\begin{array}{c}\text { PRN } \\
08\end{array}$} & 255 & \multirow{9}{*}{20.5668} & 0,2278 & \multirow{9}{*}{0.1886} & \multirow{9}{*}{20.37} & \multirow{9}{*}{20.75} \\
\hline & 254 & & 0,0939 & & & \\
\hline & 253 & & 0,115 & & & \\
\hline & 252 & & 0.01602 & & & \\
\hline & 251 & & 0.0663 & & & \\
\hline & 250 & & 0,0144 & & & \\
\hline & 249 & & 0,1015 & & & \\
\hline & 248 & & 0,079 & & & \\
\hline & 247 & & 0,135 & & & \\
\hline
\end{tabular}

\section{Stasiun BSAT PRN 08}

Setelah dilakukan Perhitungan mean dan standar deviasi diperoleh data seperti Tabel 2 kemuadian dilakukan analisa seperti Gambar 3

Dari Tabel 2 dapat dilihat bahwa terjadi variasi data pengamatan PRN 08. Dilakukan perhitungan nilai mean untuk DOY 255 diperoleh nilai 20,56. Hal ini

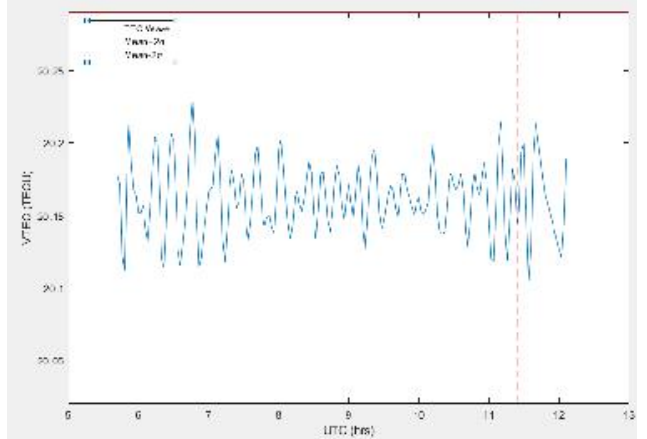

(a)

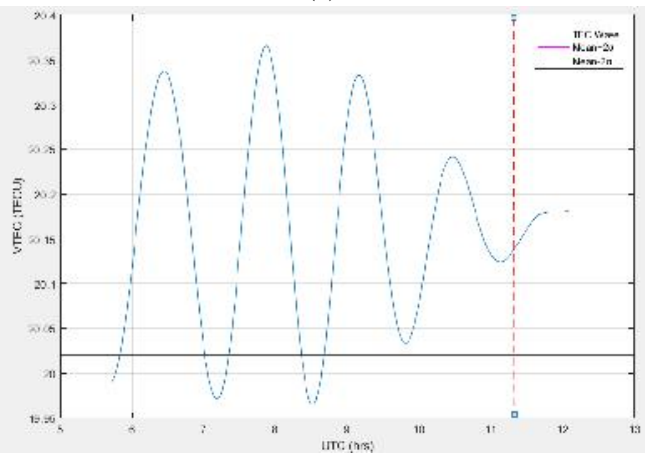

(b)

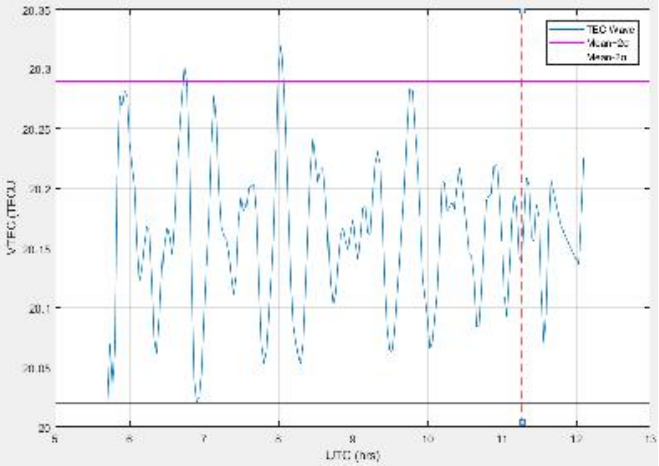

(c)

Gambar 4. (a) Gravity; Acoustic; (c) Rayleigh

Tabel 3 Hasil Perhitungan Mean dan Standar Deviasi

\begin{tabular}{ccccccc}
\hline Satelit & DOY & Mean & $\boldsymbol{\Sigma}$ & $\mathbf{2 \sigma}$ & $\begin{array}{c}\text { Mean- } \\
\mathbf{2 \sigma}\end{array}$ & Mean+2 $\boldsymbol{1}$ \\
\hline & 255 & & 0,0632 & & & \\
& 254 & & 0.0645 & & & \\
& 253 & & 0,0651 & & & \\
PRN & 252 & & 0,0655 & & & \\
$\mathbf{1 3}$ & 251 & 20,16 & 0,0655 & 0,1348 & 20,02 & 20,29 \\
& 250 & & 0,0792 & & & \\
& 249 & & 0.0771 & & & \\
& 248 & & 0,0642 & & & \\
& 247 & & 0,0623 & & & \\
\hline
\end{tabular}

dilakukan karena analisa yang dilakukan untuk melihat anomali pada DOY 255 saja. Sedangkan perhitungan standar deviasi dilakukan pada setiap data dari DOY 255 sampai DOY 247 untuk melihat trend perubahan data. $-2 \sigma$ dari mean dan $+2 \sigma$ mean diguanakan untuk mendeteksi anomali, diperoleh nilai 20,37 dan 20,75. Mengacu pada kurva lonceng, 20 memiliki akurasi sebesar 95\%. Artinya sinyal yang 
bersinggungan dengan jarak antar $-2 \sigma$ dan $+2 \sigma$ dikatakan sebagai anomali prekursor gempa bumi.

Berdasarkan Gambar 3 dapat dilihat bahwa pada PRN 08 ketika dilakukan analisis dengan frekuensi gelombang gravity dan gelombang acoustic, tidak terjadi anomali. Nilai TEC tidak mengalami perubahan yang signifikan. Hal ini dibuktikan dengan grafik TEC yang tidak bersinggungan dengan garis ungu dan hitam yang merupakan nilai standar deviasi. Analisis dengan gelombang rayleigh mendeteksi anomali 4 menit sebelum gempa, tepatnya pada pukul 11:01:48 UTC sampai pukul 11:06:03 UTC. Anomali TEC yang terjadi boleh jadi terkait dengan proses preseismik sebelum gempa bumi dan kemungkinan merupakan tanda-tanda awal terjadinya gempa bumi (prekursor).

\section{Stasiun MLKN PRN 13}

Setelah dilakukan Perhitungan mean dan standar deviasi diperoleh data seperti Tabel 3. Kemudian dilakukan analisa seperti pada Gambar 4

Berdasarkan Tabel 3 dapat dilihat bahwa terjadi variasi data pengamatan PRN 13. Dilakukan perhitungan nilai mean untuk DOY 255 diperoleh nilai 20,16. Hal ini dilakukan karena analisa yang dilakukan untuk melihat anomali pada DOY 255 saja. Sedangkan perhitungan standar deviasi dilakukan pada setiap data dari DOY 255 sampai DOY 247 untuk melihat trend perubahan data. $2 \sigma$ dari mean dan $+2 \sigma$ mean diguanakan untuk mendeteksi anomali, diperoleh nilai 20,02 dan 20,29. Mengacu pada kurva lonceng, $2 \sigma$ memiliki akurasi sebesar $95 \%$. Artinya sinyal yang bersinggungan dengan jarak antar $-2 \sigma$ dan $+2 \sigma$ dikatakan sebagai anomali prekursor gempa bumi.

Berdasarkan Gambar 4 dapat dilihat bahwa pada PRN 13 ketika dilakukan analisis dengan frekuensi gelombang gravity dan gelombang rayleigh, tidak terjadi anomali. Nilai TEC tidak mengalami perubahan yang signifikan. Hal ini dibuktikan dengan grafik TEC yang tidak bersinggungan dengan garis ungu dan hitam yang merupakan nilai standar deviasi. Analisis dengan gelombang acoustic mendeteksi anomali 5 jam sebelum gempa, tepatnya pada pukul 05:49:59 UTC sampai pukul 09:01:59 UTC. Anomali TEC yang terjadi boleh jadi terkait dengan proses preseismik sebelum gempa bumi dan kemungkinan merupakan tanda-tanda awal terjadinya gempa bumi (prekursor).

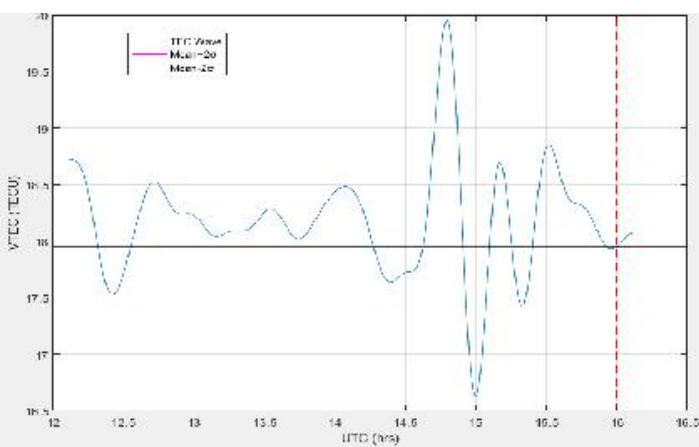

(a)

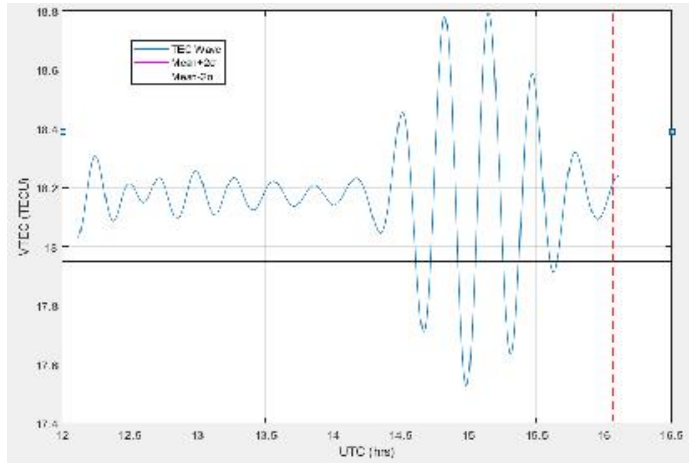

(b)

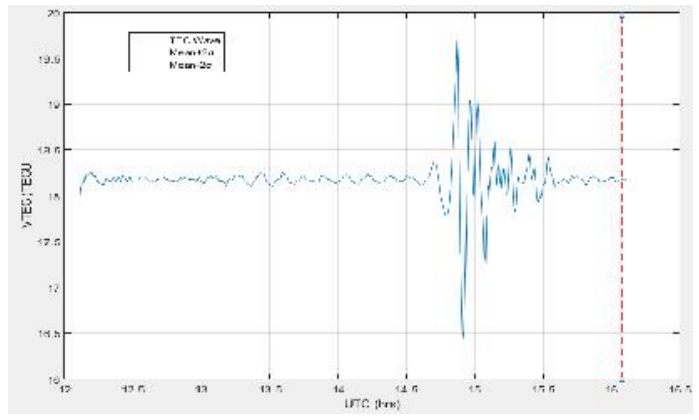

(C)

Gambar 5. (a) Gravity; Acoustic; (c) Rayleigh

Tabel 4. Hasil Perhitungan Mean dan Standar Deviasi

\begin{tabular}{ccccccc}
\hline Satelit & DOY & Mean & $\boldsymbol{\Sigma}$ & $\mathbf{2 \sigma}$ & $\begin{array}{c}\text { Mean- } \\
\mathbf{2 \sigma}\end{array}$ & Mean+2 $\boldsymbol{1}$ \\
\hline & 64 & & 0.2308 & & & \\
& 63 & & 0,1282 & & & \\
& 62 & & 0,1731 & & & \\
PRN & 61 & & 0,1731 & & & \\
$\mathbf{0 3}$ & 60 & 21,1026 & 0,0805 & 0,188067 & 20,91453 & 21,29067 \\
& 59 & & 0,1165 & & & \\
& 58 & & 0,0364 & & & \\
& 57 & & 0,0278 & & & \\
& 56 & 0,0316 & & & \\
\hline
\end{tabular}

\section{B. Gempa bumi 6.3 Mw}

Gempa bumi ini terjadi pada tanggal 05 Maret 2010 pukul 16:07:03 (UTC) pada latitude -3,85 dan longitude 100,91 dengan hiposenter $37 \mathrm{Km}$. Setelah 
dilakukan pencarian nearby site pada SOPAC maka diperoleh stasiun GPS dalam jaringan SuGAr yaitu BSAT.

\section{Stasiun BSAT PRN 03}

Setelah dilakukan Perhitungan mean dan standar deviasi diperoleh data seperti Tabel 4. Kemudian dilakukan analisa seperti Gambar 5

Berdasarkan Tabel 4 dapat dilihat bahwa terjadi variasi data pengamatan PRN 03. Dilakukan perhitungan nilai mean untuk DOY 64 diperoleh nilai 21,10, hal ini dilakukan karena analisa yang dilakukan untuk melihat anomali pada DOY 56 saja. Sedangkan perhitungan standar deviasi dilakukan pada setiap data dari DOY 64 sampai DOY 56 untuk melihat trend perubahan data. $-2 \sigma$ dari mean dan $+2 \sigma$ mean diguanakan untuk mendeteksi anomali, diperoleh nilai 20,91 dan 21,29. Mengacu pada kurva lonceng, $2 \sigma$ memiliki akurasi sebesar $95 \%$. Artinya sinyal yang bersinggungan dengan jarak antar $2 \sigma$ dan $+2 \sigma$ dikatakan sebagai anomali prekursor gempa bumi.

Berdasarkan Gambar 5 dapat dilihat bahwa pada PRN 13 ketika dilakukan analisis dengan frekeunsi gelombang gravity terdapat anomali atau perubahan nilai TEC pada ionosfer. Anomali terjadi 4 jam sebelum gempa bumi terjadi, lebih tepatnya terdeteksi pada pukul 12:15:00 UTC sampai pukul 12:37:48 UTC. Berlangsung singkat kurang lebih 22 menit kemudian anomali muncul kembali pad pukul 14:37:48 UTC sampai pukul 15:27:00. Sedangkan pada gelombang acoustic juga mendeteksi anomali pada pukul 14:32:24 UTC sampai pukul 15:36:00. Pada gelombang Rayleigh, anomali terdeteksi pada pukul 14:49:12 sampai pukul 15:08:24. Kemudian muncul anomali kembali pada pukul 15:16:12 sampai pukul 15:31:48.

\section{Gempa bumi 6.0 Mw}

Gempa bumi ini terjadi pada tanggal 04 Agustus 2011 pukul 00:16:09 (UTC) pada latitude -2,88 dan longitude 100,97 dengan hiposenter $28 \mathrm{Km}$. Setelah dilakukan pencarian nearby site pada SOPAC maka diperoleh stasiun GPS dalam jaringan SuGAr yaitu BSAT.

\section{Stasiun BSAT PRN 21}

Setelah dilakukan Perhitungan mean dan standar deviasi diperoleh data seperti Tabel 5. Kemudian dilakukan analisa seperti Gambar 6

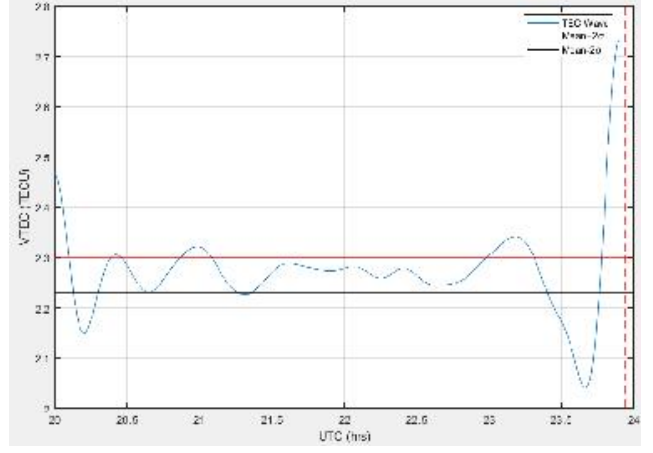

(a)

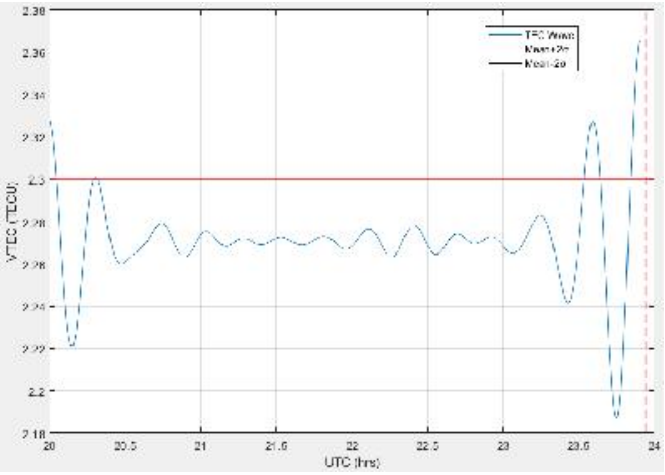

(b)

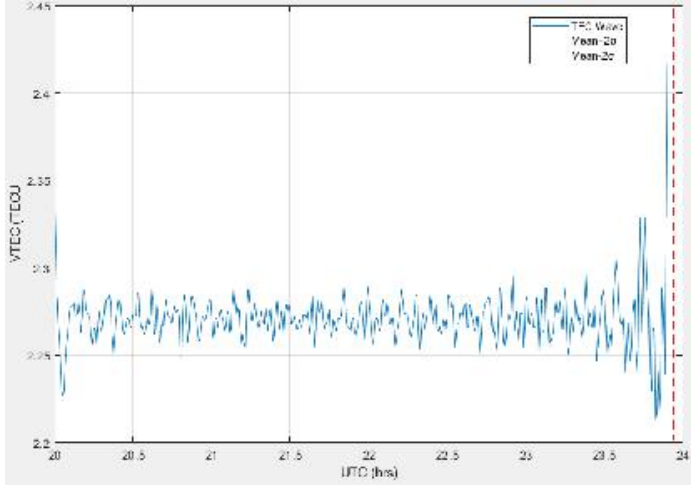

(c)

Gambar 6. (a) Gravity; Acoustic; (c) Rayleigh

Tabel 5. Hasil Perhitungan Mean dan Standar Deviasi

\begin{tabular}{|c|c|c|c|c|c|c|}
\hline Satelit & DOY & Mean & $\Sigma$ & $2 \sigma$ & $\begin{array}{c}\text { Mean- } \\
2 \sigma\end{array}$ & Mean +20 \\
\hline \multirow{9}{*}{$\begin{array}{c}\text { PRN } \\
21\end{array}$} & 216 & \multirow{9}{*}{2,2707} & 0,0147 & \multirow{9}{*}{0,03086} & \multirow{9}{*}{2,2398} & \multirow{9}{*}{2,3015} \\
\hline & 215 & & 0,0121 & & & \\
\hline & 214 & & 0,0161 & & & \\
\hline & 213 & & 0,0225 & & & \\
\hline & 212 & & 0,013 & & & \\
\hline & 211 & & 0.0123 & & & \\
\hline & 210 & & 0,0136 & & & \\
\hline & 209 & & 0,0121 & & & \\
\hline & 208 & & 0,0225 & & & \\
\hline
\end{tabular}


Berdasarkan Tabel 5 dapat dilihat bahwa terjadi variasi data pengamatan PRN 21. Dilakukan perhitungan nilai mean untuk DOY 216 diperoleh nilai 21,10, hal ini dilakukan karena analisa yang dilakukan untuk melihat anomali pada DOY 216 saja. Sedangkan perhitungan standar deviasi dilakukan pada setiap data dari DOY 216 sampai DOY 208 untuk melihat trend perubahan data. $2 \sigma$ dari mean dan $+2 \sigma$ mean diguanakan untuk mendeteksi anomali, diperoleh nilai 20,91 dan 21,29. Mengacu pada kurva lonceng, $2 \sigma$ memiliki akurasi sebesar $95 \%$. Artinya sinyal yang bersinggungan dengan jarak antar $-2 \sigma$ dan $+2 \sigma$ dikatakan sebagai anomali prekursor gempa bumi.

Dari Gambar 6 dapat dilihat bahwa pada stasiun BSAT PRN 21 ketika dilakukan analisis dengan frekeunsi gelombang gravity terdapat anomali atau perubahan nilai TEC pada ionosfer, lebih tepatnya terdeteksi pada pukul 23:48:00 UTC sampai pukul 23:54:00 UTC. anomali berlangsung singkat kurang lebih 6 menit. Sedangkan pada gelombang acoustic juga mendeteksi anomali pada pukul 20:02:24 UTC sampai pukul 20:06:36, kemudian muncul kembali pada pukul 23:37:48 sampai pukul 23:50:24. Pada gelombang Rayleigh, anomali terdeteksi pada pukul 20:00:36 UTC sampai 20:03:36 dan pukul 23:51:36 sampai pukul 23:53:24.

\section{KESIMPULAN}

Berdasarkan hasil identifikasi prekursor gempa bumi di wilayah provinsi Bengkulu. Analisis dilakukan dengan menganalisa sinyal dengan metode CWT berdasarkan range frekuensi gelombang seismik yaitu Gravity (1 mHz-2,8 mHz), Acoustic $(2,5 \mathrm{mHz}-3 \mathrm{mHz})$, dan gelombang Rayleigh $(5 \mathrm{mHz}-33 \mathrm{mHz})$. Perubahan yang terjadi di ionosfer akibat gempa bumi adalah terdapat anomali TEC dari pengolahan data satelit GPS dalam jaringan SuGAr, dimana anomali tersebut muncul 1 sampai 4 jam sebelum terjadi gempa. Dari beberapaanomali yang diperoleh dari hasil analisis dengan menggunakan standar deviasi tidak semuanya menunjukkan prekursor gempa bumi terdeteksi.

\section{REFERENSI}

[1] B. Muslim, J. Effendi, E. Aldrian, Fakhrizal, B. Sunardi and A. , "Pengembangan Sistem Monitoring Gelombang Ionosfer Terkait Gempa Bumi Menggunakan Data Gps (Gpsionoquake)," in Seminar Nasional Sains Atmosfer dan Antariksa (SNSAA) 2014 Lembaga Penerbangan dan Antariksa Nasional (Lapan), Bandung, 2014.

[2] A. M. Nur, "Gempa Bumi, Tsunami dan Mitigasinya," Jurnal Geografi, vol. 7, no. 1, p. 8, 2010.
[3] F. A. Saputra , "Analisa Perubahan Ionosfer Akibat Gempa Bumi Sumatra Barat Tanggal 2 Maret 2016," JURNAL TEKNIK ITS , vol. 6, no. 2, p. 6, 2017.

[4] T. Rikitake, Erthquake Prediction, Amsterdam: Elsevier, 1976.

[5] B. Sunardi and S. , "Pemantauan Anomali Total Electron Content (TEC) Berkaitan Dengan Kejadian Gempabumi Di Sekitar Wilayah Jawa Tahun 2015," Jurnal Fisika Dan Aplikasinya, vol. 1, no. 2, p. 6, 2016.

[6] A. G. Simanjuntak, B. Muslim and E. Hartantyo, "Identifikasi Prekursor Beberapa Gempa di Sumatera Melalui Analisis Total Electron Content (TEC) di Ionosfer Menggunakan Teknik Korelasi," in Seminar Nasional Teknofisika Nuklir 2017, Yogyakarta, 2017.

[7] G. jiming and L. Hui, "Investigation of ionosphere TEC distribution in China region by GIM model," Geo-spatial Information Science, vol. 8, no. 3, pp. 197-200, 2005. Alam, S., Surjati, I., \& Ningsih, Y. K, "Patch Modification and Slot Arrangement of Microstrip Antenna for Improving the Axial Ratio", International Conference on Broadband Communication, Wireless Sensors and Powering (BCWSP), 2017.

[8] B. Sunardi, B. Muslim and S. Pakpahan, "Anomali Total Electron Content (TEC) Sebelum Gempabumi Kuat di Indonesia Tahun 2014," in Seminar Nasional Jurusan Fisika FMIPA UNESA, Surabaya, 2015

[9] T. Iwata and K. Umeno, "Pre-seismic ionospheric anomalies detected before the 2016 Kumamoto earthquake," p. 20, 2017.

[10] T. P. S. G. Nasional, Peta Sumber Bahaya dan Bahaya Gempa di Indonesia Tahun 2017, Bandung: Pusat Penelitian dan Pengembangan Perumahan dan Pemukiman Kementerian Pekerjaan Umum dan Perumahan Rakyat , 2017, p. 361.

[11] Liu, L., W. Wan, M. L. Zhang, B. Zhao, and B. Ning, 2008b. Prestorm enhancements in $\mathrm{NmF} 2$ and total electron content at low latitudes. J. Geophys. Res., 113, A02311, doi: 10.1029/2007JA012832

[12] Muslim, B. 2015. Pengujian Teknik Autokorelasi Untuk Mendeteksi Pengaruh Aktivitas Gempa Bumi Besar Pada Ionosfer. Majalah Sains dan Teknologi Dirgantara.

[13] Foster, D.J., Mosher, C.C. dan Hassanzadeh, S., 1994, Wavelet Transform Methods for Geophysical Applications, 64th Annual International Meeting, Soc. Expl. Geophys., Expanded Abstract, halaman 1465 1468.

[14] Anant, K.S. dan Dowla, F.U., 1997, Wavelet Transform Methods for Phase Identification in Three-Component Seismograms, Bulletin of Seismological Society of America, Vol. 87, No. 6, halaman 1598 - 1612.

[15] Syauqiah, Sungkono, " Penerapan Metode Continous Wavelet Transform Data Self Potencial Studi Tanggul Lapindo," JURNAL TEKNIK ITS , vol. 6, no. 2, p. 6, 2017.

[16] E. A. Suprayitno, R. Hendradadi and A. Arifin, "Analisa Sinyal Electrocardiogrphy dan Phonocardiography secara simultan Mengggunakan Continous Wavelet Transform," in The 6th - Electrical Power, Elctronics, Communications, Controls, and Informatics Seminar 2012, Yogyakarta, 2012. 